\title{
Chemical characterization and antimicrobial activity of Campomanesia aurea against three strains of Listeria monocytogenes
}

\author{
L. A. Pacheco (D), E. M. Ethur ${ }^{\text {* (D), T. Sheibel }}$ (D), B. Buhl ${ }^{a}$ (D), A. C. Weber ${ }^{b}$ (D), \\ C. Kauffmann ${ }^{a}$ (D), M. I. Marchi ${ }^{b}$ (D), E. M. Freitas FiD $^{\text {(iD }}$ and Hoehne Ho $^{b}$ (iD \\ ${ }^{a}$ Centro de Ciências Biológicas e da Saúde, Universidade do Vale do Taquari - UNIVATES, Av. Avelino Tallini, 171, \\ Bairro Universitário, CEP 95914-014, Lajeado, RS, Brasil \\ ${ }^{\text {b} C e n t r o ~ d e ~ C i e ̂ n c i a s ~ E x a t a s ~ e ~ T e c n o l o ́ g i c a s, ~ U n i v e r s i d a d e ~ d o ~ V a l e ~ d o ~ T a q u a r i ~-~ U N I V A T E S, ~ A v . ~ A v e l i n o ~ T a l l i n i, ~ 171, ~}$ \\ Bairro Universitário, CEP 95914-014, Lajeado, RS, Brasil \\ *e-mail: eduardome@univates.br
}

Received: February 13, 2019 - Accepted: October 4, 2019 - Distributed: February 28, 2021

\begin{abstract}
The essential oil (EO) composition of leaves of Campomanesia aurea was analyzed by GC-MS. The plant was collected in April (EOA) and October (EOO) in São Francisco de Assis/RS. The essential oils were obtained by hydrodistillation in a modified Clevenger apparatus. The yields were $4.44 \%$ in April, and 6.15\%, in October. Thirty-one compounds were identified in EOA, accounting for $96.87 \%$ of the total, and twenty-eight compounds were identified in EOO, accounting for $99.46 \%$ of the total. For EOA, the major identified monoterpene was $p$-cymene $(8.33 \%)$ and the major identified sesquiterpene was $\alpha$-cadinol (10.72\%), while regarding EOO the major identified monoterpene was repeatedly Terpinolene (3.43\%), whereas the major identified sesquiterpene was $\alpha$-cadinol (12.79\%). The antibacterial activity of the essential oil was evaluated against the three Listeria monocytogenes from the American Type Culture Collection (strains ATCC 7644, 19114 and 13932). The essential oil showed a MIC of $10 \mathrm{mg} / \mathrm{mL}$ against the strains ATCC 7644 and 19114, with bacteriostatic effect of $20 \mathrm{mg} / \mathrm{mL}$ and a MIC of $20 \mathrm{mg} / \mathrm{mL}$ for ATCC 13932. Regarding the antibiofilm activity, o EOO showed the best results with an inhibition of $90 \%$ in the sessile growth with an applied concentration of $4.0 \mathrm{mg} / \mathrm{mL}$.
\end{abstract}

Keywords: essential oil, Pampa biome, antimicrobial activity, Campomanesia aurea, Listeria monocytogenes.

\section{Caracterização química e atividade antimicrobiana de Campomanesia aurea contra três cepas de Listeria monocytogenes}

\section{Resumo}

O óleo essencial (EO) das folhas de Campomanesia aurea foi analisado por CG-EM. O A planta foi coletada em abril (OEA) e outubro (OEO) em São Francisco de Assis/RS. Os óleos essenciais foram obtidos por hidrodestilação em aparelho Clevenger modificado. Os rendimentos foram de 4,44\% em abril e 6,15\% em outubro. Trinta e um compostos foram identificados no EOA, representando $96,87 \%$ do total, e vinte e oito compostos foram identificados no EOO, representando 99,46\% do total. Para EOA, o principal monoterpeno identificado foi o p-cimeno (8,33\%) e o principal sesquiterpeno identificado foi o $\alpha$-candinol (10,72\%), enquanto o EOO o maior monoterpeno identificado foi repetidamente Terpinolene (3,43\%), enquanto o sesquiterpeno principal identificado foi $\alpha$-cadinol (12,79\%). A atividade antibacteriana do óleo essencial foi avaliada contra as três cepas de Listeria monocytogenes obtidas a partir da American Type Culture Collection (isolados ATCC 7644, 19114 and 13932). O óleo essencial apresentou uma CIM de $10 \mathrm{mg} / \mathrm{mL}$ contra as cepas ATCC 7644. e 19114, com efeito bacteriostático de 20 mg/mL e MIC de $20 \mathrm{mg} / \mathrm{mL}$ para ATCC 13932. Quanto à atividade antibiofilme, o EOO apresentou os melhores resultados com uma inibição de $90 \%$ no crescimento séssil com uma concentração aplicada de $4,0 \mathrm{mg} / \mathrm{mL}$.

Palavras-chave: óleo essencial, bioma Pampa, atividade antimicrobiana, Campomanesia aurea, Listeria monocytogenes.

\section{Introduction}

Campomanesia aurea $\mathrm{O}$. Berg (Myrtaceae) is popularly known as "goiabinha-do-campo" (Lorenzi et al., 2006) and is a native plant in Brazil, which possess ornamental potential, occurring from the region of Cerrado in the south of the state São Paulo to the region Pampa, located at the south of the state Rio Grande do Sul (RS) (Emer et al., 2018; Sobral et al., 2013). In the literature, species of the genus Campomanesia sp. are related to folk medicine for different 
purposes, as for example the leaves of Campomanesia adamantium (Cambess) O.Berg are commonly used for treatment of urinary tract infections, whereas the use of Campomanesia xanthocarpa is recommended against high triglyceride and cholesterol levels, urethritis, cystitis, as well as reduction of glycaemia, or treatment of intestinal transit and rectal prolapses. The species Campomanesia aurea is used in respect to its astringent effect and as a fragrant, when the leaves and tree barks are used (Coutinho et al., 2010; Feijó et al., 2012; Mentz et al., 1997).

The bacterial species Listeria monocytogenes is principally related to ingestion of contaminated food. This pathogen can grow in a wide range of temperature and $\mathrm{pH}$ ( $1{ }^{\circ} \mathrm{C}$ to $45^{\circ} \mathrm{C}$ and $\mathrm{pH} 4.3$ to 9.6 ), as well as tolerating elevated salt concentrations, which hampers its elimination (Hamidiyan et al., 2018). L. monocytogenes is known to cause the disease listeriosis, which affects principally immunocompromised patients, thereby having a mortality rate of $30 \%$. Furthermore, the bacteria bear the ability for biofilm formation, and by this way developing resistance to sanitizers and antimicrobial agents, thus provoking serious problems to food industries (Oliveira et al., 2016b; Rogalla and Bomar, 2018; Marini et al., 2018).

The increasing development of multi resistant bacteria may be consequently the inefficiency of the already existent antibiotics, thus leading to an elevated effort in the research field for plant derived bioactive compounds, which was our focus in the present study, evaluating the antimicrobial potential of Campomanesia aurea. Plant species of the family Myrtaceae, just as the genus Campomanesia sp. are widely studied, due to their range of secondary metabolites, which are related to different biological activities, but with a special emphasis for the antimicrobial activity against L. monocytogenes. The essential oils of the species of the genus Eucalyptus sp. (E. camaldulensis, E. astringens, E. leucoxylon, E. lehmannii, E. rudis, E. cinereal and E. sideroxylon) showed expressive activity levels against Listeria strains (Figueiredo et al., 2019; Sebei et al., 2015). Victória et al. (2012) evaluated the antimicrobial potential against L. monocytogenes ATCC 19117 and encountered promising results for regarding antimicrobial activity.

For these reasons, the present study aimed to evaluate the antimicrobial activity of the essential oils of C. aurea, collected at two different times of the year, against the strains Listeria monocytogenes ATCC 19114, 13932 and 7644.

\section{Material and Methods}

\subsection{Plant material}

The leaves of Campomanesia aurea were collected in

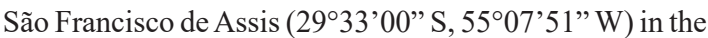
months of April and October of 2017. The identification of this material was done by Prof. Dr. E. M. de Freitas and one specimen of the plant material was archived in the herbarium of the Museum of Natural Sciences (Museu de Ciências Naturais) of the University of Vale do Taquari - RS - Brazil, under the code HVAT 5093.

\subsection{Obtainment of the essential oil}

The essential oil of $C$. aurea was extracted by hydrodistillation using a modified Clevenger apparatus. A quantity of $150 \mathrm{~g}$ of leaves were boiled in water at a proportion of 1:20, for $3.5 \mathrm{~h}$. The essential oil was removed with gravity, then dried with anhydrous sodium sulfate and kept in amber flasks, at $-6^{\circ} \mathrm{C}$, until further chemical or biological examinations.

\subsection{Chemical analysis of the essential oil}

Samples of EOA and EOO were analyzed by gas chromatography coupled to mass spectrometry (GC-MS) (Kauffmann et al., 2017), at the Instrumental Analysis Laboratory, Food Processing Development Centre - FPDC, Univates. Analysis was performed on a Shimadzu GC2010 Plus system, comprising a model AOC-5000 Plus auto injector and a model QP2110 Ultra mass detector, using a Restek Rtx ${ }^{\circledR}-5 \mathrm{MS}$ fused silica capillary column $(30 \mathrm{~m} \times 0.25 \mathrm{~mm}$ i.d.; $0.25 \mu \mathrm{m}$ film thickness). The chromatographic conditions were: carrier gas - helium at a flow rate of $1.00 \mathrm{~mL} / \mathrm{min}$; oven temperature - initially at $50{ }^{\circ} \mathrm{C}$ and increased at $4{ }^{\circ} \mathrm{C} / \mathrm{min}$ to $290{ }^{\circ} \mathrm{C}$; injector temperature $-240{ }^{\circ} \mathrm{C}$; injection mode - split with $1: 20$ ratio and $3 \mathrm{~mL} / \mathrm{min}$ purge; MS interface temperature $-280{ }^{\circ} \mathrm{C}$; ion source temperature $-260{ }^{\circ} \mathrm{C}$; ionization energy - $70 \mathrm{eV}$. Oil samples (15 mg) were dissolved in $1.5 \mathrm{~mL}$ of purified ethyl acetate and aliquots of $1 \mu \mathrm{L}$ were injected for analysis. GC analysis with flame ionization detection (FID) was carried out using an Agilent J\&W HP-5MS column $(30 \mathrm{~m} \times 0.25 \mathrm{~mm}$ i.d.; $0.25 \mu \mathrm{m}$ film thickness) with helium as carrier gas, a FID temperature of $260^{\circ} \mathrm{C}$ and an oven temperature program as described for the GC-MS procedure.

Separated components were initially identified by their Kováts retention indices (RI), determined by a series of $n$-alkanes as a reference (Van Den Dool and Dec. Kratz, 1963). Their identities were confirmed by comparison of the mass spectral data with those obtained using pure standards together with values quoted in the literature (Adams, 2012) and data stored in the Wiley 8 and NIST11 spectral libraries of the analytical system. The relative composition of the oils was calculated from the peak areas (uncorrected for specific response factors) of the separated components.

\subsection{Bacterial isolates}

To evaluate the antimicrobial potential, Listeria monocytogenes isolates, stored at the American Type Culture Collection (ATCC) were used (ATCC 7644; 19114 and 13932). The microorganisms could be obtained in lyophilized form from the Laboratory for Reference Microorganisms of the Oswaldo Cruz Foundation (Laboratório de Microrganismos de Referência da Fundação Oswaldo Cruz) - FIOCRUZ. The bacterial strains were cultivated on Listeria specific supplemented Oxford Agar Base and incubated at $37{ }^{\circ} \mathrm{C}$ for 24 hours. 


\subsection{Preparation and standardization of the inoculums}

The resuspended isolates of $L$. monocytogenes were transferred to sterile Petri dishes containing supplemented Oxford Agar Base and incubated at $37^{\circ} \mathrm{C} \pm 1{ }^{\circ} \mathrm{C}$ for 24 hours. Thereafter, the inoculums for the MIC and antibiofilm assays were prepared in test tubes containing $10 \mathrm{~mL}$ of sterile $0.85 \%$ saline solution and mixed for 1 minute using a vortex agitator. To standardize the inoculums, the turbidity was measured by UV/visible spectrophotometry (Thermo Fisher Scientific, model G10S UV-VIS CAT 840-208100, SN 2L5Q326116) at $625 \mathrm{~nm}$. An obtained absorbance between $0.08-0.13$ indicated a bacterial density of $1.5 \times 10^{8} \mathrm{CFU} / \mathrm{mL}$, corresponding to a value of 0.5 at the nephelometric McFarland scale.

\subsection{Minimal inhibitory concentration and minimal bactericidal concentration}

The minimum inhibitory concentration (MIC) was determined using the broth dilution methodology in sterile 96-well microtiter plates (CLSI, 2012) and performed in triplicate with each bacterial strain. Initially, an aliquot of the essential oil prepared in TWIN $80^{\circledR}$ was transferred to a test tube containing TSB broth. $100 \mu \mathrm{L}$ of the microbial suspension $\left(1.5 \times 10^{6} \mathrm{CFU} / \mathrm{mL}\right)$ and $100 \mu \mathrm{L}$ of essential oil solubilized in water and $0.8 \%$ of TWIN $80(40 \mu \mathrm{L} / \mathrm{mL})$ was added to each well. Then, serial dilutions were performed resulting in concentrations of $20-0.625 \mathrm{mg} / \mathrm{mL}$. The plates were incubated at $37^{\circ} \mathrm{C}$ for $24 \mathrm{~h}$. As a negative control for broth sterility and bacterial growth, wells without bacterial inoculum were prepared. Chloramphenicol was used as a positive control to prevent bacterial growth.

After incubation in a bacteriological incubator $\left(37^{\circ} \mathrm{C}\right.$ for 24 hours), $16 \mu \mathrm{L}$ 3-(4,5-dimethyl-2-thiazolyl)-2,5-diphenyl2H-tetrazolium bromide (MTT, Sigma Aldrich, St. Louis, MO, USA) (dissolved in sterile phosphate buffered saline solution up to a concentration of $5 \mathrm{mg} / \mathrm{mL}$ ) was added to each well. The MIC was defined as the minor sample concentration in the test resulting in complete inhibition of microbial growth.

The MBC was realized by inoculation of supplemented Oxford Agar with all well contents, for which no red coloring could be observed. Subsequently, the plates were incubated $\left(37^{\circ} \mathrm{C}\right.$ for 24 hours). The concentration of the essential oils, which inhibited bacterial growth, was considered as the $\mathrm{MBC}$.

\subsection{Antibiofilm activity}

For evaluation of the antibiofilm potential, strains of the American Type Culture Collection (ATCC) Listeria monocytogenes (ATCC 7644; 13932; 19114) were used. To determine bacterial adhesion ability 96-well microtiter plates with flat bottom (Corning Incorporated, USA) were used as a model made of hydrophobic material. The bacteria were cultivated on Oxford Agar overnight in an incubator at $37^{\circ} \mathrm{C}$. Thereafter, for use in the assays, a bacterial suspension with sterile saline solution was prepared, corresponding to $3 \times 10^{8} \mathrm{CFU} / \mathrm{mL}$.

\subsection{Antibiofilm activity assay}

To realize the antibiofilm activity assays there was used the methodology of Trentin et al. (2011). To each well of the microtiter plate were added $80 \mu \mathrm{L}$ of the bacterial suspension, $40 \mu \mathrm{L}$ of the essential oil sample and $80 \mu \mathrm{L}$ of tryptone soy broth (TSB) (Oxoid Ltd., England). The samples were tested at concentrations of $0.4 \mathrm{mg} / \mathrm{mL}$ and $4.0 \mathrm{mg} / \mathrm{mL}$. The plates were incubated at $37^{\circ} \mathrm{C}$, for 24 hours. Thereafter, the content of the wells was discarded, and the wells were washed for three times with sterile saline solution. The plate was placed into an incubator at $60{ }^{\circ} \mathrm{C}$ for one hour to fix the formed biofilm. The biofilm was stained with a $0.4 \%$ crystal violet solution and incubated at room temperature for 15 minutes. Thereafter, $200 \mu \mathrm{L}$ of ethanol (Synth ${ }^{\circledR}$, Brazil) were added to solubilize the dye and the absorbance was measured at $570 \mathrm{~nm}$ with a microtiter plate reader (SpectraMax i3x Multimode Microplate Reader, Molecular Devices, USA).

The absorbance of the growth control, for which the essential oil sample was substituted by adding $40 \mu \mathrm{L}$ of sterile water, was considered as $100 \%$ biofilm formation, and were used as a baseline to calculate the inhibition of the biofilm formation for the analyzed samples. Values above $100 \%$ were evaluated as stimulation of the biofilm formation compared to the growth control.

\subsection{Bacterial growth assay}

The growth of planktonic bacteria was determined by the difference of the absorbance, measured at $600 \mathrm{~nm}$ using a microplate reader (SpectraMax i3x Multimode Microplate Reader, Molecular Devices, USA) at time point zero and after 24 hours.

To the bacterial growth control were added $40 \mu \mathrm{L}$ sterile water instead of the sample, and this positive control was considered as $100 \%$ planktonic bacterial growth. Values above $100 \%$ were evaluated as stimulation of bacterial growth with respect to the control. As a negative control for bacterial growth, gentamycin $0.16 \mathrm{mg} / \mathrm{mL}$ (Sigma-Aldrich Co., USA) and vancomycin $0.16 \mathrm{mg} / \mathrm{mL}$ (Sigma-Aldrich Co., USA) were utilized.

\subsection{Statistical analysis}

The samples were analyzed in quadruplicate, and the experiments realized in triplicate. The results were expressed as mean percentage \pm standard deviation. The significance of the differences between the samples was calculated with t-Student test, using the software BioEstat 5.0, and considering values of $p \leq 0.05$ as significant difference.

\section{Results and Discussion}

The yield of the essential oils of the plant species, collected in São Francisco de Assis/RS was 4.44\% for the oil obtained in April (EOA), and $6.15 \%$ for the oil obtained in October (EOO). 


\subsection{Characterization of the constituents of the essential oils}

In terms of analysis of the essential oils, 31 components could be identified for the oil collected in April (EOA), and 28 components for the plant material collected in October (EOO), comprising monoterpenes and sesquiterpenes (Table 1).

Miranda et al. (2016) highlights the monoterpenes and sesquiterpenes as the principal constituents encountered in essential oils, which corroborate with the obtained data in this study. It could be observed that the collected oil in the cold period showed the highest quantity of hydrocarbon monoterpenes. By contrast, the oxygenated monoterpenes were the main components of the collected samples in the heat period.

In the present study, the compound 1,8-cineole was observed in both sample collections, showing a concentration of $5.13 \%$ for the EOA, and $2.14 \%$ for the EOO, which may explain, that the oil produced in April had higher activity than that of the plant material collected

Table 1. Chemical constituents of the essential oils obtained from the leaves of Campomanesia aurea, collected in April and October in São Francisco de Assis/RS.

\begin{tabular}{|c|c|c|c|c|}
\hline \multirow{2}{*}{ Compound } & \multirow{2}{*}{ RI exp. ${ }^{a}$} & \multirow{2}{*}{ RI lit. ${ }^{b}$} & \multicolumn{2}{|c|}{ Relative composition (\%) } \\
\hline & & & April & October \\
\hline$\alpha$-Thujene & 929 & 930 & 1.59 & 2.70 \\
\hline$\alpha$-Pinene & 936 & 939 & 6.80 & 6.68 \\
\hline$\beta$-Pinene & 978 & 979 & 4.85 & 6.61 \\
\hline Myrcene & 991 & 990 & & 0.93 \\
\hline$\alpha$-Phellandrene & 1006 & 1002 & & 1.68 \\
\hline$\delta$-3-Carene & 1012 & 1013 & & 0.27 \\
\hline$\alpha$-Terpinene & 1017 & 1017 & & 1.58 \\
\hline p-Cymene & 1024 & 1024 & 8.33 & 0.97 \\
\hline Limonene & 1028 & 1029 & 2.00 & 1.22 \\
\hline 1,8-Cineole & 1031 & 1031 & 5.13 & 2.14 \\
\hline$\beta-(E)$-Ocimene & 1047 & 1050 & & 0.29 \\
\hline$\gamma$-Terpinene & 1057 & 1059 & 3.03 & 6.03 \\
\hline Cis-linalool oxide & 1072 & 1072 & 0.41 & \\
\hline Terpinolene & 1088 & 1088 & 3.46 & 9.83 \\
\hline Linalool & 1100 & 1096 & 6.77 & 9.12 \\
\hline Terpinene-4-ol & 1178 & 1177 & 4.85 & 2.33 \\
\hline$p$-Cymen-8-ol & 1186 & 1182 & 0.99 & \\
\hline$\alpha$-Terpineol & 1192 & 1188 & 7.38 & 4.32 \\
\hline Ethyl geranate & 1386 & 1395 & 0.79 & \\
\hline (E)-Cariofilene & 1420 & 1419 & 0.53 & 0.86 \\
\hline$\alpha$-Humulene & 1454 & 1454 & 0.67 & 0.61 \\
\hline allo-Aromadendrene & 1462 & 1460 & 2.38 & 2.00 \\
\hline Bicyclogermacrene & 1499 & 1500 & 1.76 & \\
\hline$\alpha$-Muurolene & 1503 & 1500 & 1.24 & 1.29 \\
\hline$\gamma$-Cadinene & 1515 & 1513 & 1.80 & 1.00 \\
\hline$\delta$-Cadinene & 1525 & 1523 & 5.95 & 8.99 \\
\hline (E)-Nerolidol & 1564 & 1563 & 1.11 & 2.34 \\
\hline Palustrol & 1569 & 1568 & 0.60 & \\
\hline Spathulenol & 1579 & 1578 & 4.20 & \\
\hline n.i. ${ }^{c}$ & 1585 & 1585 & 2.42 & \\
\hline n.i. & 1600 & 1600 & 0.71 & \\
\hline Ledol & 1606 & 1602 & 1.25 & \\
\hline 1-epi-Cubenol & 1631 & 1628 & 1.53 & \\
\hline epi- $\alpha$-Muurolol & 1645 & 1642 & 7.92 & 8.24 \\
\hline$\alpha$-Muurolol & 1649 & 1646 & 1.38 & 0.96 \\
\hline$\alpha$-Cadinol & 1658 & 1654 & 10.72 & 12.79 \\
\hline n.i. & 1782 & 1782 & & 1.13 \\
\hline$(E, E)$-Geranyl linalool & 2031 & 2027 & & 0.53 \\
\hline
\end{tabular}

${ }^{\mathrm{a}}$ Experimental retention index; ${ }^{\mathrm{b}}$ Retention index according to literature (Adams, 2012); ${ }^{\mathrm{c}}$ Not identified. 
Table 1. Continued...

\begin{tabular}{|c|c|c|c|}
\hline \multirow{2}{*}{ Compound } & \multirow{2}{*}{ RI lit. ${ }^{b}$} & \multicolumn{2}{|c|}{ Relative composition (\%) } \\
\hline & & April & October \\
\hline Total identified & & 96.87 & 99.46 \\
\hline Total of hydrocarbon monoterpenes & & 30.06 & 38.79 \\
\hline Total of oxygenated monoterpenes & & 25.53 & 18.70 \\
\hline Total of hydrocarbon sesquiterpenes & & 12.57 & 16.51 \\
\hline Total of oxygenated sesquiterpenes & & 28.71 & 25.46 \\
\hline Other oxygenated compounds & & & 0.53 \\
\hline
\end{tabular}

${ }^{\mathrm{a}}$ Experimental retention index; ${ }^{\mathrm{b}}$ Retention index according to literature (Adams, 2012); ${ }^{\mathrm{c}}$ Not identified.

in October. However, the other substances encountered in lower proportions within the essential oils, additionally can have impact to the biological activity. Accordingly, the potential depends on the activity of this constituent, or its possible synergism with the other components of the oil (Castro et al., 2016; Lima et al., 2014). It also could be observed, that in both collections, the identified main component of the essential oils was $\alpha$-cadinol, with $10.72 \%$ and $12.79 \%$ respectively.

Regarding the characterization of the oils by $\mathrm{GC} / \mathrm{MS}$, it could be observed, that the EOA presented a higher total quantity of oxygenated monoterpenes and sesquiterpenes, compared to the EOO.

Besides the main compound $\alpha$-cadinol in both oils (EOA and EOO), there were also identified the substances $\alpha$-pinene, $\beta$-pinene, $p$-cymene, 1,8-cineole, terpinolene, linalool, $\alpha$-terpineol, $\gamma$-cadinene and epi- $\alpha$-muurolol in higher proportion. One fact, that stands out, is that 10 of the identified constituents in the EOA were not present in the EOO. These data corroborate with those of the study of Cerqueira et al. (2009), where the seasonal variation of the essential oil composition of Myrcia salzmannii Berg. (Myrtaceae) was evaluated. As one sampling took place in February, and the other in October, likewise a decrease of the components could be observed in October, characterized as the end of winter, compared to the month February as the end of summer, which indicates, that the difference of the chemical composition can be attributed to the climatic changes of these two seasons. During different seasons, the compounds $\alpha$-phellandrene, $\delta$ - 3 -carene, $\alpha$-terpinene, 1,8-cineole, $\beta$ - $(E)$-ocimene and $(E, E)$-geranyl linalool could be identified as compounds related to the winter, as there were no detectable in the sampling material of April. Cis-linalool oxide, $p$-cymen-8-ol, ethyl geranate, bicyclogermacrene, palustrol, spathulenol, ledol and 1-epi-cubenol, were only identified as a constituent of the essential oil collected in summer. Spathulenol is related to various activities, amongst them antimicrobial activity for the genus Campomanesia (Pastori et al., 2013; Oliveira et al., 2016a). By the fact, that this compound was present in the EOA, but absent in EOO, it could be responsible for the higher activity of the EOA, obtained in summer.

\subsection{Antimicrobial activity}

By comparison of the results for the essential oils of $C$. aurea against the three L. monocytogenes strains ATCC 7644 and ATCC 19114, the EOA showed a higher activity as the EOO, thus it could be observed, that the result was the same for all three strains with a MIC of $10 \mathrm{mg} / \mathrm{mL}$ without any bactericide effect, however, bacteriostatic effect at the concentrations of $20 \mathrm{mg} / \mathrm{mL}$ and $10 \mathrm{mg} / \mathrm{mL}$. At concentrations $<10 \mathrm{mg} / \mathrm{mL}$ there was no activity. For the strain L. monocytogenes ATCC 13932, the activity of the EOA was lower than for the other tested strains, showing a MIC of $20 \mathrm{mg} / \mathrm{mL}$, furthermore no bactericide potential, nor bacteriostatic effect at a concentration of $20 \mathrm{mg} / \mathrm{mL}$. Values $<20 \mu \mathrm{g} / \mathrm{mL}$ for the EOA did not show any activity. For the EOO, there could not be shown any activity at the tested concentrations, thus suggesting higher virulence of the strain ATCC 13932.

Some studies indicated that the essential oils have antimicrobial activity against many pathogens, regarding bacteria, as well as fungi (Ferronatto et al., 2007; Santurio et al., 2011). Marini et al. (2018), tested the antimicrobial activity of the essential oil of Cannabis sativa against Listeria monocytogenes, and obtained the $\mathrm{MBC} \geq 2.048 \mathrm{mg} / \mathrm{mL}$, thus suggested bactericidal activity due to the presence of the identified main compounds of the oil, myrcene and $\alpha$-pinene. These two substances could also be identified in the present study, specifically the $\alpha$-pinene in both oils (EOA and EOO) and the myrcene only in the EOO.

Oxygenated monoterpenes are shown to be the principal constituents of essential oils, possessing antimicrobial activity against various microorganisms, implying L. monocytogenes, which can be specifically related to the chemical constituents 4-terpineol and 1,8-cineole; a result, which was also encountered in this study (Castro et al., 2016; Silva et al., 2019).

Differences between the essential oils could be observed, however, it was not possible to recognize a specific reason. One can suspect, that due to the results, the essential oils showed a variation regarding the components within its composition, which occurred for different extractions and for different seasons, thus some components may possess specific ability to burst the barrier and penetrate the bacterial membrane, probably due to their hydrophobic character (Santurio et al., 2011).

These data corroborate with the findings of Ferraz et al. (2018), when they discussed, that there are chemical differences between different plant species, and even between members of the same species, however, observational cultivated during different times of the year. These plants showed different arising constituents of their secondary 
Table 2. Antibiofilm activity of the essential oils of Campomanesia aurea, against Listeria monocytogenes ATCC 13932 , 19114 and 7644.

\begin{tabular}{|c|c|c|c|c|}
\hline \multirow{2}{*}{ ATCC 13932} & \multicolumn{2}{|c|}{ Bacterial growth (\%) } & \multicolumn{2}{|c|}{ Biofilm formation (\%) } \\
\hline & $0.4 \mathrm{mg} / \mathrm{mL}$ & $4 \mathrm{mg} / \mathrm{mL}$ & $0.4 \mathrm{mg} / \mathrm{mL}$ & $4 \mathrm{mg} / \mathrm{mL}$ \\
\hline EOA & $118.11 \pm 40.52$ & $59.35 \pm 8.35^{*}$ & $39.28 \pm 4.73 *$ & $10.03 \pm 3.21 *$ \\
\hline EOO & $142.89 \pm 2.22 *$ & $52.03 \pm 11.15^{*}$ & $17.98 \pm 4.31 *$ & $3.57 \pm 0.41 *$ \\
\hline \multirow{2}{*}{ ATCC 19114} & \multicolumn{2}{|c|}{ Bacterial growth (\%) } & \multicolumn{2}{|c|}{ Biofilm formation (\%) } \\
\hline & $0.4 \mathrm{mg} / \mathrm{mL}$ & $4 \mathrm{mg} / \mathrm{mL}$ & $0.4 \mathrm{mg} / \mathrm{mL}$ & $4 \mathrm{mg} / \mathrm{mL}$ \\
\hline $\mathrm{EOA}$ & $56.88 \pm 15.46^{*}$ & $43.91 \pm 4.79 *$ & $33.59 \pm 3.93 *$ & $13.95 \pm 1.92 *$ \\
\hline EOO & $131.02 \pm 16.84 *$ & $8.82 \pm 1.17 *$ & $37.27 \pm 3.12 *$ & $5.25 \pm 0.57 *$ \\
\hline \multirow{2}{*}{ ATCC 7644} & \multicolumn{2}{|c|}{ Bacterial growth (\%) } & \multicolumn{2}{|c|}{ Biofilm formation (\%) } \\
\hline & $0.4 \mathrm{mg} / \mathrm{mL}$ & $4 \mathrm{mg} / \mathrm{mL}$ & $0.4 \mathrm{mg} / \mathrm{mL}$ & $4 \mathrm{mg} / \mathrm{mL}$ \\
\hline EOA & $68.82 \pm 8.02 *$ & $45.86 \pm 0.34^{*}$ & $27.53 \pm 6.73 *$ & $15.62 \pm 3.19 *$ \\
\hline EOO & $76.44 \pm 0.65^{*}$ & $8.34 \pm 4.74^{*}$ & $48.40 \pm 7.81^{*}$ & $5.67 \pm 0.04 *$ \\
\hline
\end{tabular}

*significant difference in relation to the growth control $(p \leq 0.05)$.

metabolism, resulting in different biological activities. In general, the antimicrobial effects occur due to structural and functional damages at the cytoplasmic membrane, principally through hydrophobicity of the substances, present in the essential oil, as well as influences in the enzymatic system and genetic material of the bacteria. Therefore, qualitative analysis of the essential oils can reveal potentially important substances enhancing control of bacterial growth and contamination, also to evaluate, if the compounds show a better activity when isolated or when associated as a consequence of synergistic effect (Doherty et al., 2011; Ferraz et al., 2018).

\subsection{Antibiofilm activity}

The oils of $C$. aurea showed significant activity against biofilm formation, as it can be consulted in Table 2 .

The essential oils of the species $C$. aurea showed significant results, underlining the efficiency of the EOO against the tested bacterial strains, with inhibition higher than $90 \%$ at a concentration of $4.0 \mathrm{mg} / \mathrm{mL}$. Sessile growth was determined with $3.57 \% \pm 0.41,5.25 \% \pm 0.57$ and $5.63 \% \pm 0.04$, without interfering planktonic growth, for the strain ATCC 13932 for both oils (EOA and EOO), and for the strain ATCC 19114 for the EOO, respectively (Table 2).

The best results, regarding biofilm formation, could be obtained for the EOO at concentrations of 0.4 and $4 \mathrm{mg} / \mathrm{mL}$ $(17.98 \% \pm 4.31$ and $3.57 \% \pm 0.41 \%)$, against $L$. monocytogenes ATCC 13932. The second-best results could be encountered for the EOA with sessile growth of $10.03 \% \pm 3.21$ for strain ATCC $13932(4.0 \mathrm{mg} / \mathrm{mL})$ and of $27.53 \% \pm 6.73$ for strain ATCC $7644(0.4 \mathrm{mg} / \mathrm{mL})$.

The EOO showed significant activity for planktonic cell growth at a concentration of $4 \mathrm{mg} / \mathrm{mL}$ for L. monocytogenes ATCC 19114 and 7644. These data are in accordance with those, encountered by assaying the antimicrobial activity within this study.

Sá et al. (2018), evaluated the antimicrobial activity for Campomanesia adamantium against strains of Listeria, including the strain ATCC 7644, which showed a MIC of $0.03125 \mathrm{mg} / \mathrm{L}$.
Plants, belonging to the family Myrtaceae are utilized in folk medicine regarding their diuretic action, as anti-fever, anti-rheumatic, and anti-inflammatory agent, and for control of glycemia, amongst many others (Victória et al., 2012; Simonetti, 2016).

In conclusion, considering the impact provoked by biofilm forming microorganisms, as the bacteria species L. monocytogenes, as well as the difficulties in removing such contaminants, the present study showed, that the essential oils of $C$. aurea exhibited higher antibiofilm activity compared to inhibition of planktonic growth. The EOO, even comprising a smaller number of constituents, showed higher activity when compared to the EOA. Therefore, being tested for the first time, the antimicrobial and antibiofilm activity of the EO of the native plant species $C$. aurea showed sufficient capability against $L$. monocytogenes, for what reason a prospective evaluation of the comprising oil components in separately may be worthwhile, because some can show an enhanced promising efficiency, and not only for antimicrobial or antibiofilm activity, but also in other research fields, studying plant derived bioactive components.

\section{Acknowledgements}

This study was financed in part by the Coordenação de Aperfeiçoamento de Pessoal de Nível Superior - Brasil (CAPES) - Finance Code 001.

\section{References}

ADAMS, R.P., 2012. Identification of essential oil components by gas chromatography/mass spectrometry. 4th ed. Carol Stream: Allured Publishing Corporation, $804 \mathrm{p}$.

CASTRO, K.N.C., LIMA, D.F., VASCONCELOS, L.C., SANTOS, R.C., PEREIRA, A.M.L., FOGAÇA, F.H.S.F., CANUTO, K.N., BRITO, E.S. and CALVET, R.M., 2016. Composição química e eficácia do óleo essencial e do extrato etanólico de Alpinia zerumbet sobre Staphylococcus aureus. Arquivos do Instituto Biológico, vol. 83, no. 0, pp. e0192014. http://dx.doi.org/10.1590/18081657000192014 
CERQUEIRA, M.D., MARQUES, E.J., MARTINS, D., ROQUE, N.F., CRUZ, F.G. and GUEDES, M.L.S., 2009. Variação sazonal da composição do óleo essencial de Myrcia salzmannii Berg. (Myrtaceae). Química Nova, vol. 32, no. 6, pp. 1544-1548. http:// dx.doi.org/10.1590/S0100-40422009000600035.

CLINICAL AND LABORATORY STANDARDS INSTITUTE - CLSI, 2012. Methods for dilution antimicrobial susceptibility test for bacteria that grow aerobically. Wayne: CLSI. NCCLS document M07-A9.

COUTINHO, I.D., KATAOKA, V.M.F., HONDA, N.K., COELHO, R.G., VIEIRA, M.C. and CARDOSO, C.A.L., 2010. Influência da variação sazonal nos teores de flavonóides e atividade antioxidante das folhas de Campomanesia adamantium (Cambess.) O. Berg, Myrtaceae. Brazilian Journal of Pharmacognosy, vol. 20, no. 3, pp. 322-327. http://dx.doi.org/10.1590/S0102-695X2010000300006.

DOHERTY, V.F., OLANIRAN, O.O. and KANIFE, U.C., 2011. Antimicrobial activities of Aframomum melegueta (Alligator Pepper). Brazilian Journal of Biology $=$ Revista Brasileira de Biologia, vol. 2, no. 2, pp. 126-131. http://dx.doi.org/10.5539/ ijb.v2n2p126.

EMER, A.A., SCHAFER, J. and FIOR, C.S., 2018. Estaquia de Campomanesia aurea O. Berg (Myrtaceae): época de coleta de propágulos e efeito de auxina. Revista Brasileira de Ciências Agrárias, vol. 13, no. 1, pp. e5494. http://dx.doi.org/10.5039/ agraria.v13i1a5494.

FEIJÓ, A.M., BUENO, M.E.N., CEOLIN, T., LINCK, C.L., SCHWARTZ, E., LANGE, C., MEINCKE, S.M.K., HECK, R.M., BARBIERI, R.L. and HEIDEN, G., 2012. Plantas medicinais utilizadas por idosos com diagnóstico de Diabetes mellitus no tratamento dos sintomas da doença. Revista Brasileira de Plantas Medicinais, vol. 14, no. 1, pp. 50-56. http://dx.doi.org/10.1590/ S1516-05722012000100008.

FERRAZ, E.O., VIEIRA, M.A.R., FERREIRA, M.I., FERNANDES JUNIOR, A., MARQUES, M.O.M., MINATEL, I.O., ALBANO, M., SAMBO, P. and LIMA, G.P.P., 2018. Seasonality effects on chemical composition, antibacterial activity and essential oil yield of three species of Nectandra. PLoS One, vol. 13, no. 9, pp. e0204132. http://dx.doi.org/10.1371/journal.pone.0204132. PMid:30226853.

FERRONATTO, R., MARCHESAN, E.D., PEZENTI, E., BEDNARSKI, F. and ONOFRE, S.B., 2007. Atividade antimicrobiana de óleos essenciais produzidos por Baccharis dracunculifolia D.C. e Baccharis uncinella D.C. (Asteraceae). Revista Brasileira de Farmacognosia, vol. 17, no. 2, pp. 224-230. http://dx.doi. org/10.1590/S0102-695X2007000200016.

FIGUEIREDO, P.L.B., PINTO, L.C., COSTA, J.S., SILVA, A.R.C., MOURÃO, R.H.V., MONTENEGRO, R.C., SILVA, J.K.R. and MAIA, J.G.S., 2019. Composition, antioxidant capacity and cytotoxic activity of Eugenia uniflora L. chemotype-oils from the Amazon. Journal of Ethnopharmacology, vol. 232, pp. 30-38. http://dx.doi.org/10.1016/j.jep.2018.12.011. PMid:30543916.

HAMIDIYAN, N., SALEHI-ABARGOUEI, A., REZAEI, Z., DEHGHANI-TAFTI, R. and AKRAMI-MOHAJERI, F., 2018. The prevalence of Listeria spp. food contamination in Iran: a systematic review and meta-analysis. Food Research International, vol. 107, pp. 437-450. http://dx.doi.org/10.1016/j.foodres.2018.02.038. PMid:29580505.

KAUFFMANN, C., PACHECO, L.A., BUHL, B., SCHEIBEL, T., FREITAS, E.M., HOEHNE, L., MACHADO, G.M.C., CAVALHEIRO, M.M.C., GNOATTO, S.C.B. and ETHUR,
E.M., 2017. Avaliação da atividade leishmanicida in vitro de espécies da família Myrtaceae, nativas do sul do Brasil. Revista Destaques Acadêmicos, vol. 9, no. 3, pp. 246-258. http://dx.doi. org/10.22410/issn.2176-3070.v9i3a2017.1530.

LIMA, A.S., SOUSA FILHO, J.G.M., PEREIRA, S.G., GUILLON, G.M.S.P., SANTOS, L.S. and COSTA JÚNIOR, L.M., 2014. Acaricide activity of different extracts from Piper tuberculatum fruits against Rhipicephalus microplus. Parasitology Research, vol. 113, no. 1, pp. 107-112. http://dx.doi.org/10.1007/s00436013-3632-8. PMid:24221883.

LORENZI, H., BACHER, L., LACERDA, M. and SARTORI, S., 2006. Frutas brasileiras e exóticas cultivadas. Nova Odessa: Instituto Plantarum, $672 \mathrm{p}$.

MARINI, E., MAGI, G., FERRETTI, G., BACCHETTI, T., GIULIANI, A., PUGNALONI, A., RIPPO, M.R. and FACINELLI, B., 2018. Attenuation of Listeria monocytogenes Virulence by Cannabis sativa L. essential oil. Frontiers in Cellular and Infection Microbiology, vol. 8, pp. 293. http://dx.doi.org/10.3389/ fcimb.2018.00293. PMid:30186775.

MENTZ, L.A., LUTZEMBERGER, L.C. and SCHNKEL, E.P., 1997. Da flora medicinal do Rio Grande do Sul: notas sobre a obra de D’ávila (1910). Caderno de Farmácia, vol. 13, no. 1, pp. 25-48.

MIRANDA, C.A.S.F., CARDOSO, M.G., BATISTA, L.R., RODRIGUES, L.M.A. and FIGUEIREDO, A.C.S., 2016. Óleos essenciais de folhas de diversas espécies: propriedades antioxidantes e antibacterianas no crescimento espécies patogênicas. Ciência Agronômica, vol. 47, no. 1, pp. 213-220. http://dx.doi. org/10.5935/1806-6690.20160025.

OLIVEIRA, J.D., ALVES, C.C.F., MIRANDA, M.L.D., MARTINS, C.H.G., SILVA, T.S., AMBROSIO, M.A.L.V., ALVES, J.M. and SILVA, J.P., 2016a. Rendimento, composição química e atividades antimicrobiana e antioxidante do óleo essencial de folhas de Campomanesia adamantium submetidas a diferentes métodos de secagem. Revista Brasileira de Plantas Medicinais, vol. 18, no. 2, pp. 502-510. http://dx.doi.org/10.1590/1983-084X/15_206.

OLIVEIRA, L.B.S., BATISTA, A.H.M., FERNANDES, F.C., SALES, G.W.P. and NOGUEIRA, N.A.P., 2016b. Atividade antifúngica e possível mecanismo de ação do óleo essencial de folhas de Ocimum gratissimum (Linn.) sobre espécies de Candida. Revista Brasileira de Plantas Medicinais, vol. 18, no. 2, pp. 511523. http://dx.doi.org/10.1590/1983-084X/15_222.

PASTORI, T., FLORES, F.C., BOLIGON, A.A., ATHAYDE, M.L., SILVA, C.B., CANTO-DOROW, T.S. and TEDESCO, S.B., 2013. Genotoxic effects of Campomanesia xanthocarpa extracts on Allium cepa vegetal system. Pharmaceutical Biology, vol. 51, no. 10, pp. 1249-1255. http://dx.doi.org/10.3109/13880209.201 3.786097. PMid:23848305.

ROGALLA, D. and BOMAR, P.A., 2018. Listeria Monocytogenes. Treasure Island: StatPearls. PMid:30521259.

SÁ, S., CHAUL, L.T., ALVES, V.F., FIUZA, T.S., TRESVENZOL, L.M.F., VAZ, B.G., FERRI, P.H., BORGES, L.L. and PAULA, J.R., 2018. Phytochemistry and antimicrobial activity of Campomanesia adamantium. Revista Brasileira de Farmacognosia, vol. 28, no. 3, pp. 303-311. http://dx.doi.org/10.1016/j.bjp.2018.02.008.

SANTURIO, D.F., COSTA, M.M., MABONI, G., CAVALHEIRO, C.P., SÁ, M.F., DAL POZZO, M., ALVES, S.H. and FRIES, L.L.M., 2011. Atividade antimicrobiana de óleos essenciais de condimentos frente a amostras de Escherichia coli isoladas de aves e bovinos. Revista Cientifica Rural, vol. 41, no. 6, pp. 10511056. http://dx.doi.org/10.1590/S0103-84782011005000067. 
SEBEI, K., SAKOUHI, F., HERCHI, W., KHOUJA, M.L. and BOUKHCHINA, S., 2015. Chemical composition and antibacterial activities of seven eucalyptus species essential oils leaves. Biological Research, vol. 48, no. 1, pp. 7. http://dx.doi. org/10.1186/0717-6287-48-7. PMid:25654423.

SILVA, E.A.J., ESTEVAM, E.B.B., SILVA, T.S., NICOLELLA, H.D., FURTADO, R.A., ALVES, C.C.F., SOUCHIE, E.L., MARTINS, C.H.G., TAVARES, D.C., BARBOSA, L.C.A. and MIRANDA, M.L.D., 2019. Antibacterial and antiproliferative activities of the fresh leaf essential oil of Psidium guajava L. (Myrtaceae). Brazilian Journal of Biology = Revista Brasileira de Biologia, vol. 79, no. 4, pp. 697-702. http://dx.doi.org/10.1590/15196984.189089. PMid:30462815.

SIMONETTI, E., 2016. Avaliação da atividade antimicrobiana de extratos de Eugenia anomala e Psidium salutare (Myrtaceae) frente à Escherichia coli e Listeria monocytogenes. Lajeado: Programa de Pós-graduação em Biotecnologia, Centro Universitário UNIVATES, 101 p. Dissertação de Mestrado em Biotecnologia.

SOBRAL, M., PROENÇA, C., SOUZA, M., MAZINE, F. and LUCAS, E. 2013 [viewed 13 February 2019]. Myrtaceae: lista de espécies da Flora do Brasil [online]. Rio de Janeiro: Jardim
Botânico do Rio de Janeiro. Available from: http://floradobrasil. jbrj.gov.br

TRENTIN, D.S., GIORDANI, R.B., ZIMMER, K.R., SILVA, A.G., SILVA, M.V., CORREIA, M.T., BAUMVOL, I.J. and MACEDO, A.J., 2011. Potential of medicinal plants from the Brazilian semi-arid region (Caatinga) against Staphylococcus epidermidis planktonic and biofilm lifestyles. Journal of Ethnopharmacology, vol. 137, no. 1, pp. 327-335. http://dx.doi.org/10.1016/j.jep.2011.05.030. PMid:21651970.

VAN DEN DOOL, H. and DEC. KRATZ, P., 1963. A generalization of the retention index system including linear temperature programmed gas-liquid partition chromatography. Journal of Chromatography A, vol. 11, pp. 463-471. http://dx.doi.org/10.1016/ S0021-9673(01)80947-X. PMid:14062605.

VICTORIA, F.N., LENARDÃO, E.J., SAVEGNAGO, L., PERIN, G., JACOB, R.G., ALVES, D., SILVA, W.P., MOTTA, A.S. and NASCENTE, P.S., 2012. Essential oil of the leaves of Eugenia uniflora L.: antioxidant and antimicrobial properties. Food and Chemical Toxicology, vol. 50, no. 8, pp. 2668-2674. http://dx.doi. org/10.1016/j.fct.2012.05.002. PMid:22583648. 